\title{
Analysis after Brexit: European integration has started in the areas previously blocked by London
}

\begin{abstract}
The approach to identifying practical problems is in the interaction between the United Kingdom (UK) and the European Union (EU), the consequences of the UK's withdrawal from the EU, and ways to overcome them by coordinating national institutes' activities in the UK and the EU. The specific research results that characterize the novelty of the study are as follows: it was found that the UK's withdrawal from the EU is a specific form of manifestation of the global tendency to revive elements of isolationism in international economic relations; it was found that the work of the European Commission and the UK government on further cooperation between the EU and the UK can be used to create models of cooperation between the Eastern Partnership countries and the EU in the future. The aim is to study the theoretical and practical foundations of the European integration of the UK in retrospective and modern times to identify problems of cooperation with the EU, a general analysis of the causes and possible consequences of leaving the EU, prospects for further development.
\end{abstract}

Keywords: Brexit, United Kingdom, European Union, GDP, COVID-19, integration JEL Classification Codes: F36, F50, G33, H61, N40, P16

\footnotetext{
1 University of Social Sciences, Faculty of Management and Security, Warsaw, Poland, e-mail: msvirniuk @gmail.com, https://orcid.org/0000-0003-2966-6351
} 


\section{Analiza po brexicie. Integracja europejska rozpoczęła się w obszarach wcześniej blokowanych przez Londyn}

\section{Streszczenie}

Identyfikacja problemów praktycznych w interakcjach między Wielką Brytanią a Unią Europejską obejmuje konsekwencje wystąpienia Wielkiej Brytanii z Unii Europejskiej oraz sposoby przezwyciężenia tych problemów poprzez koordynację działań krajowych instytucji w Wielkiej Brytanii i krajach członkowskich Unii Europejskiej. Konkretne wyniki stanowiące nowe elementy w przedstawionym badaniu są następujące. Stwierdzono, że wystąpienie Wielkiej Brytanii z Unii Europejskiej jest specyficzną formą manifestacji globalnej tendencji do odradzania się elementów izolacjonizmu w międzynarodowych stosunkach gospodarczych. Stwierdzono także, że prace Komisji Europejskiej i rządu Wielkiej Brytanii nad dalszą współpracą między Unią Europejską a Wielką Brytanią mogą w przyszłości zostać wykorzystane do opracowania modeli współpracy między krajami Partnerstwa Wschodniego a Unią Europejską. Celem przedstawionej analizy było zbadanie teoretycznych i praktycznych podstaw integracji europejskiej w Wielkiej Brytanii w ujęciu zarówno retrospektywnym, jak i współczesnym, identyfikacja problemów we współpracy z Unią Europejską, analiza ogólnych przyczyn i możliwych konsekwencji wyjścia z Unii Europejskiej oraz perspektywy dalszego rozwoju relacji.

Słowa kluczowe: brexit, Wielka Brytania, Unia Europejska, PKB, COVID-19, integracja Kody klasyfikacji JEL: F36, F50, G33, H61, N40, P16

The processes of European integration, which officially began in the second half of the $20^{\text {th }}$ century, are marked by a long and rich history, the evolutionary development of thinking about European unity over many centuries. This need to unite European countries and states in creating a space of security to overcome conflicts has created favorable conditions for the development of integration processes on the continent.

A significant impetus for the practical implementation of the integration project was also to reduce the vulnerability of national economies to the world market, a high level of economic development, efficient use of resource potential, creating a positive ground for the functioning of international business structures/institutions, and obtaining benefits from closer cooperation between national farms. A key role in the reconstruction of Europe was played by the Marshall Plan, according to which 16 post-war European countries received about 17 billion dollars from the United States (US). This plan was also used to finance their economy (see Markova, Krivtsova, and Kvasov, 1995: 195). Thus, all the factors became available for global 
development and characteristic of Western Europe, which laid the foundation for building European unity.

In a different position of each of the leading countries, this should be noted:

1. The United Kingdom (UK) had the most substantial economic position in postwar Europe. Simultaneously, close ties with the US gave carte blanche a leading role among other Western European countries. However, even under these conditions, Britain did not envisage the possibility of any restrictions on its sovereignty or counterbalance to other European countries.

2. France, unlike the UK, insisted on the creation of a supranational "European federation" and planned to become its leader.

3. Germany gradually turned from a subject to an object of international relations.

4. The US was the most crucial party in the Organisation for European Economic Co-operation "Unification of Europe" project, which paved the way for future independent European initiatives designed to implement the Marshall Plan.

The UK, which had been an associate member of the European Coal and Steel Community (ECSC) since 1954, became more active in the late 1950s. Despite the signing of the Treaties of Rome on the European Economic Community (EEC) and the European Atomic Energy Community with the six countries on March 25, 1957, negotiations with Britain progressed slowly. They lasted until January 1, 1959, even before the introduction of the first measures to liberalize domestic trade.

The EEC and Euratom governments became a decisive step towards implementing the European integration strategy, which paved the way for constructing a common Europe but without the UK. Under these conditions, in order to prevent other European countries from approaching the EEC, the UK made it possible to unite countries that had not entered the common market. As a result, the Convention establishing the European Association was signed on January 4, 1960, in Stockholm.

Denmark, Sweden, Norway, and Portugal, which had close ties with the UK, as well as Austria, Switzerland, later Finland, and Iceland, joined the EFTA. The trend towards relatively rapid economic growth in six countries intensified amid a slowdown in the world economy. Thus, between 1958 and 1970, GDP production reached $226 \%$ in Germany, $207 \%$ in Italy, $172 \%$ in France, but only $83 \%$ in Britain. Therefore, the development of integration showed the apparent advantages of a united Europe.

In the autumn of 1961, the British government decided to start negotiations on its membership in the EEC. The desire to have a special status within the community means that the UK will use the tactic of gradually discussing a range of issues, which, in turn, delays the negotiations. Also, the situation became more complicated when the US reported on the Atlantic partnership with Western Europe, where the UK acted as a guarantor of US interests on the European continent. 
In late 1950, the British economy proved to be one of the weakest in Western Europe, lagging behind France's, Germany's, and Italy's growth rates. For the second time, the UK applied for its membership in the EEC, on May 11, 1967, with Ireland and Denmark, on July 24 with Norway. Bringing other EEC countries closer to the UK, Charles de Gaulle decided to block its accession to the Community without starting negotiations with the Member States, again pointing to the need to improve the economy.

It became clear that the UK could not become a member of the EEC while de Gaulle was in power. Only after de Gaulle's resignation in 1969 French President Georges Pompidou lifted the veto on Britain's membership of the EEC. The Accession Treaty was signed on January 22, 1972, and it entered into force on January 1, 1973. Following the accession to the European Union (EU), the UK improved rapidly its economic development indicators to a great extent. However, following the accession of the UK to the Community, the problems associated with its accession did not end.

Britain wanted to become a member of a united Europe, and it joined the EEC under special conditions, in 1974. The Labour Party, which came to power, raised the issue of revising a number of accession conditions. On June 5, 1975, a national referendum on the country's membership in the EEC was held for the first time in London, in which $67.2 \%$ of the votes were cast in support of EEC membership (see, among other things, Derega, 2008: 120-139).

Currently, in addition, not only Brexit but also the pandemic of COVID-19 has worsened the economic situation in the EU and the UK. COVID-19 is affecting the economic deterioration of the EU and the UK. Every month the economies of the $\mathrm{EU}$ and the UK suffer more and more. Companies go bankrupt, GDP falls, investments run out. Due to this, the EU has adopted a unique package of financial assistance to somehow save the economies of these countries.

Table 1. Negative impacts of Brexit on the United Kingdom and the European Union

\begin{tabular}{|l|l|}
\hline \multicolumn{1}{|c|}{ For the United Kingdom } & \multicolumn{1}{c|}{ For the European Union } \\
\hline $\begin{array}{l}\text { A decrease in demand for financial services at the expense } \\
\text { of EU Member States and likely relocation of some financial } \\
\text { institutions to Vienna, Frankfurt, and Paris. }\end{array}$ & $\begin{array}{l}\text { The transformation from a domestic to a British } \\
\text { overseas market, which accounts for } 16 \text { to } 21 \% \text { of } \\
\text { other EU countries' exports of goods and services. }\end{array}$ \\
\hline $\begin{array}{l}\text { Difficult access to EU goods and financial markets, which } \\
\text { account for 45\% of British exports. }\end{array}$ & $\begin{array}{l}\text { The overall decline of the EU economy and its } \\
\text { importance to the world economy as the EU's share of } \\
\text { the world's population has fallen from } 7 \% \text { to } 6.1 \%, \text { of } \\
\text { the world GDP from } 23.8 \% \text { to } 20 \%, \text { and of exports from } \\
33.9 \% \text { to 30.3\%. }\end{array}$ \\
\hline
\end{tabular}




\begin{tabular}{|c|c|}
\hline For the United Kingdom & For the European Union \\
\hline $\begin{array}{l}\text { Inflationary pressures caused by higher prices for goods } \\
\text { imported from the EU, Britain runs a persistently negative } \\
\text { trade balance with the EU mainland due to the payment of } \\
\text { additional customs duties and VAT. }\end{array}$ & $\begin{array}{l}\text { The migration crisis has worsened due to the UK's } \\
\text { refusal to accept illegal migrants from other EU } \\
\text { countries. }\end{array}$ \\
\hline $\begin{array}{l}\text { Loss of influence over the adoption of EU regulatory rules, } \\
\text { which will still have a major impact on bilateral economic } \\
\text { relations, as well as using the political weight of the entire EU } \\
\text { to regulate economic relations with third countries. }\end{array}$ & $\begin{array}{l}\text { Setting a dangerous precedent for leaving the EU } \\
\text { to create a situation of uncertainty and instability in the } \\
\text { EU economy. }\end{array}$ \\
\hline $\begin{array}{l}\text { At the same time, these losses can be partly offset by } \\
\text { ending annual payments to the EU general budget of up } \\
\text { to } £ 13 \text { billion, of which only } £ 7 \text { billion are repayable in return } \\
\text { subsidies. The positive impact of this factor will, however, } \\
\text { be tempered by the need to negotiate separately on trade } \\
\text { regimes with some particularly important partners in which } \\
\text { these issues are now being negotiated with the EU, and } \\
\text { the need for a separate negotiation process with certain } \\
\text { particularly important partners, in which these issues are } \\
\text { now being addressed. However, the a positive influence of } \\
\text { this factor will be tempered by the need to negotiate separate } \\
\text { trade regulations with some particularly important partners, } \\
\text { with whom these issues now have been settled as part of } \\
\text { their relationship with the EU in total, namely about nearly } 60 \\
\text { countries, above all, Japan, China, Australia, and the US. }\end{array}$ & $\begin{array}{l}\text { The loss of the City of London as the leading financial } \\
\text { center not only in Europe but also in the world will } \\
\text { limit the ability to implement effective financial and } \\
\text { investment policies. }\end{array}$ \\
\hline
\end{tabular}

Source: own elaboration.

Table 2. Advantages and disadvantages of Brexit for the United Kingdom

\begin{tabular}{|c|c|}
\hline Advantages & Disadvantages \\
\hline Own control of immigration processes. & $\begin{array}{l}\text { Separation from a common political direction with the } \\
\text { countries of Europe. }\end{array}$ \\
\hline Solving the migration crisis at the national level. & Defining the rights of British citizens in the EU. \\
\hline Establishing new, more profitable trade agreements. & A decrease in trade and economic activity. \\
\hline $\begin{array}{l}\text { Establishing own tariffs for trade in goods and services } \\
\text { with other countries. }\end{array}$ & $\begin{array}{l}\text { Introducing tariffs for the export of goods from Britain } \\
\text { to EU countries. }\end{array}$ \\
\hline $\begin{array}{l}\text { A money-saving solution to the non-payment of } \\
\text { membership fees to the EU. }\end{array}$ & Reducing the number of jobs. \\
\hline National control of employment and healthcare. & A risk to future trade and adverse economic agreements. \\
\hline Relocation of global corporations to the UK. & $\begin{array}{l}\text { Regulation of the residence and work rights of British } \\
\text { citizens in the EU and the EU citizens in the UK. }\end{array}$ \\
\hline
\end{tabular}

Source: own elaboration.

\section{COVID-19 and the European Union's economy}

Huge losses, unpaid taxes, unemployment, stock market crashes, and stock depreciation are a reality. The world's political alliance with a population of around 450 million has suffered more than others. As for the US, the world's leading economy, 
the coronavirus pandemic came later and has not yet harmed them as much as the EU. The GDP in the US fell by $1.2 \%$ compared to $3.5 \%$ in the EU. The annual rate of economic decline in the EU in the first quarter exceeded 13\%, compared to a modest $4.8 \%$ in the US.

At the end of the year (Editor's note: as of 2020), Europe will lag even further behind its competitors. According to the International Monetary Fund, the EU's economy will suffer most $(-7 \%)$, more than in the US $(-6 \%)$ and Japan $(-5 \%)$, as well as a competitor of the EU in the fight for the title of the world's second-largest economy, China will avoid a general economic downturn (+1.2\%). As it is the country where the COVID-19 pandemic began, China will still observe economic growth at the end of the year. However, according to the Chinese National Statistics Office, between January and February 2020, industrial production in China fell by $13.5 \%$, sales fell by $20.5 \%$, and investment by $24.5 \%$.

With an average European decline of 3.5\%. France's GDP fell by $5.8 \%$, Spain's by $5.2 \%$, and Italy's by $4.7 \%$. On March 13, 2020. The European Commission presented a package of measures to compensate partially for the coronavirus pandemic economic damage. The European Investment Bank has raised EUR 40 billion to support companies affected by the coronavirus spread. In turn, the European Commission intends to create an anti-crisis fund for EUR 37 billion, but is this enough money? Experts from the Centre for Economic and Policy Studies (CEPR) argue that the EU must spend USD 350 billion to compensate for the loss of 30 days of quarantine.

On May 20, 2020, the Council of the EU decided to provide EUR 3 billion in financial assistance to ten enlargement and neighborhood partners. The purpose of this support is to help overcome the negative economic consequences of the COVID-19 pandemic. Financial assistance will be provided in the form of loans on very favorable terms. It will be distributed as follows: Albania: EUR 180 million, Bosnia and Herzegovina: EUR 250 million, Georgia: EUR 150 million, Jordan: EUR 200 million, Kosovo: EUR 100 million, Moldova: EUR 100 million, Montenegro: EUR 60 million, North Macedonia: EUR 160 million, Tunisia: EUR 600 million, and Ukraine: EUR 1.2 billion.

EU assistance will help these countries cover their immediate financial needs increased by the pandemic. Together with the International Monetary Fund's support, these measures will help strengthen macro-economic stability and promote the free disposal of resources to protect citizens and mitigate the socio-economic impact of the pandemic.

The funds will be available for 12 months and will be paid out in 2 installments. The maximum average maturity will be 15 years. A Memorandum of Understanding will cover assistance agreed between the Commission and each partner country (see, in particular, the Council of the European Union, 2020). 
With regard to the UK, on March 11, 2020, the Bank of England announced a reduction in the base rate by half a percent, the easing of banking conditions imposed on banks, and the launch of a new small business financing mechanism. The Minister of Finance of the UK, Rishi Sunak, completed this monetary component by announcing a plan for the economic recovery of 30 billion GBP (EUR 33.5 billion) during the first British budget presentation after Brexit.

\section{The difference between the United Kingdom and the European Union in the matter of European integration, the causes of Brexit}

The difference between the UK and the EU is one of the most critical issues in the EU's functioning. The British government as well as the governments of Poland and the Czech Republic, to protect their national interests, have not agreed to the binding nature of the Charter of Fundamental Rights of the European Union. Following the entry into force of the Lisbon Treaty on December 1, 2009. The Charter of Fundamental Rights of the European Union was fully extended to the UK. Global geopolitical changes in the 1990s sparked a serious debate in the EU over the foreign policy change.

The European Monetary System was founded in 1979; the UK was one of the first Member States to leave the exchange rate mechanism. During the preparation of the Treaty on the European Union (1992), the UK agreed to sign the Treaty on two conditions. First, it did not want to take part in the final phase of the Economic and Monetary Union formation, and therefore, it did not switch to the EUR. Secondly, it did not join the text of the agreement on social policy signed by the other 11 Member States of the EU. It did not join the single visa regime, which corresponds to most Schengen countries in the EU (see, in particular, Hrubinko, 2014).

There was also an EU budget issue between the UK and the EU; the UK believed that the least acute problem is the unequal distribution of the budget burden. The UK, Italy, and France were responsible for reviewing the rules, unlike Germany, which required compliance with the budgetary rules. The main budget contributors were Germany, France, Italy, and the UK. The primary recipients were Poland, Spain, France, and Germany. That is why the "UK Amendments" were used to correct the excessive "Member States contributions" to the budget, especially of the UK during 2007-2013: 66\% was the difference between the country's contribution to the budget and the fact that it took the money in the form of grants and technical projects assistance. However, Germany, the Netherlands, Austria, and Sweden paid 
only $25 \%$ in their usual funding of the UK compensation share (see, among others, Makarenko, Khomutenko, and Diakonova, 2014: 344).

The most challenging issue for Britain and Europe was the problem of immigration, which, among other reasons, played a catalytic role in the secession from the EU. Since 2015 Europe has been facing the most significant wave of migration since the mid-1990s. These are refugees from the warring countries of Africa and the Middle East: from Syria, Afghanistan, Libya, Iraq, and other countries that seek asylum in Europe, mainly in the most developed economic countries of the Old World (see, among others, the Independent Analytical Centre for Geopolitical Research Borisfen Intel, 2015).

Thus, the reasons for Britain's withdrawal from the EU have long been agreed upon, and the idea that without the EU Britain's economic situation will improve, and the problems will be solved is quite useful and real in the minds of many Britons.

\section{Socio-economic risks for the United Kingdom and the European Union from the disintegration}

The referendum on Britain's withdrawal from the EU was a significant challenge for both sides. The withdrawal from the EU can have severe, primarily economic consequences for both the UK and the EU itself. Given this, and even more so, to assess the consequences, it is difficult, but also extremely important, to understand all the expected changes for all the actors in international relations. In this regard, it is necessary to identify the main problem areas and possible risks. According to experts, Brexit will cost the British 56 billion EUR a year. GDP growth per capita also indicates a slowdown in growth and declining incomes in general. However, the UK's level of GDP per capita is higher than in most EU countries and is USD 39,000. However, Britain's withdrawal from the EU has a number of significant disadvantages, including the closure of banks and bankruptcy of companies, which can lead to unemployment. The future of Britain depends, in particular, on foreign companies, if they will stay in Britain or close down their branches until better times, and on whether the British will create the necessary number of jobs in the country without any help.

The uncertainty about Britain's economic development prospects in the new environment is of concern to the world community in terms of financial implications. London is the largest financial center, not only in Europe but also in the world. Over the last year, EUR 350 billion, which is about 17\% of all European banks' investments in the British economy, was withdrawn from island assets by continental bankers. 
Bank assets decreased from EUR 1.94 trillion to EUR 1.59 trillion, bank liabilities from EUR 1.67 trillion to EUR 1.34 trillion (see, among other things, Vardanean, 2017).

The UK Finance Ministry warned that if the UK leaves the EU, it will not add $3.4 \%$ to $9.5 \%$ of GDP in 15 years. In turn, the state budget may not receive from 20 to 45 billion GBP in taxes. The impact analysis and the development of possible exit scenarios have been involved in current economic policies, as has the UK and the EU countries and their economic partners. Let us look at three scenarios to support this view. This is evidenced by the analytical report submitted by the UK Finance Ministry in April 2017. According to the report, there are three scenarios in the UK with corresponding "exit prices" in the event of leaving the EU.

The Norwegian scenario assumes that the country will remain part of the European Economic area, retain access to the single free market in the EU, and will have to follow specific rules in Brussels. In this case, it will face a drop in GDP of 3.8\% (compared to the situation if the country remained in the EU), each year it will cost 2,600 GBP a year, and the country will lose taxes up to 20 billion EUR a year.

The second Canadian scenario assumes that the UK will sign a bilateral trade agreement with the EU (as Canada did). Then the country will lose $6.2 \%$ of GDP, it will cost households GBP 4300 per year, and the British will lose taxes of 36 billion per year. The WTO scenario assumes that the UK will not conclude a separate agreement with the EU but will be subject to WTO terms and conditions. Under this scenario, it will lose $7.5 \%$ of GDP. The scenario costs GBP 5200 per year in taxes for households, and the country could lose GBP 45 billion per year. In addition, the Minister of Finance warned of the prospect of reducing budget expenditure in the areas such as education and healthcare by about 36 billion GBP. After the first stage of negotiations on Brexit, it became clear that the UK would not follow the Norwegian scenario.

The UK accounted for around 10\% of the EU's budget revenue. After Britain's departure from the EU, it will not receive between 12 and 15 billion EUR a year. This was stated by Günther Oettinger, a member of the European Commission on Budget in Brussels, presenting at the conference the landmarks for the EU - MFF (Multiannual Financial Framework) after 2020. According to him, the implementation of new tasks for 2020 requires high costs. In the new EU budget plan, the EU will continue to address, such as the migration crisis and refugee assistance, border control, defense funding, research, and development support. The additional package will be several billion a year. To fill the gaps in the EU budget after Brexit, the Member States' contributions will increase, for example, in the case of Germany, this means an increase of $16 \%$ or EUR 3.8 billion (see, among other things, Gschwendtner, 2017). 
The analysis of 12 different models was presented by the Peterson Institute for World Economy (Washington, DC) in the spring of 2019. The report is titled Brexit: they lose everything, but the UK loses the most (Latorre, Olekseyuk, Yonezawa and Robinson, 2019). According to this study, Britain's losses can range from $-1.2 \%$ to $-4.5 \%$ of its GDP if it does not sign a trade agreement with the EU and the parties return to trade under the rules of the World Trade Organization rules.

It remains to be seen how Britain will fill the budget gap after Brexit, whether it will depend on how the EU continues to unite the continent: to take advantage of such cooperation, or conversely, to pay too high a price to leave it. This could fundamentally change the approach of European capitals to Brussels.

\section{Impact on world trade}

The UK had to change two governments to achieve an exit from the EU, but the most challenging part of the Brexit talks is still to come in the future. The fact is that by the end of 2020 - the transition period - the UK should sign new trade agreements with the EU, the US, and many other countries. Meanwhile, the UK will remain part of the common European market, and the EU customs union provides for dutyfree trade. The future of British goods, as well as European exports to the UK, will depend on how London and Brussels agree on duty-free trade. If such negotiations fail and the UK imposes tariffs on EU goods, they could cost up to 5 billion EUR a year.

The calculation is based on the previous tariff schedule announced by the UK authorities for a complex Brexit. According to it, goods worth EUR 47.3 billion (16\%) out of EUR 301.2 billion of European exports to the UK (in 2018), would be exposed to the new tariffs (see, in particular, Pogkas, Diamond, 2020).

The EU can also take appropriate action on goods from the UK. The Confederation of British Industry predicts that in the event of a failure in trade negotiations, the duty could cover $90 \%$ of Britain's exports to the EU. If London and Brussels fail to agree at all, they will be forced to trade according to the World Trade Organization rules. Analysts warn against an economic shock for both sides. European Commission President Ursula von der Leyen reminded that a comprehensive trade agreement with London by the end of 2020 would be "virtually impossible." At the same time, US Finance Minister Steve Mnuchin said that the US hopes to sign a trade agreement with the UK by the end of the year. 


\section{Terms for further cooperation between the United Kingdom and the European Union}

The process of Britain's withdrawal from the EU was initiated in accordance with Article 50 of the Treaty on the Functioning of the EU, which provides for such procedures for withdrawal. This process should not take more than two years. One of the main problems faced by the UK and the EU during the negotiation process was the development of a specific algorithm of optimal interaction in such dimensions as the geostrategic, institutional, market, financial, etc.

Basically, the negotiation process itself was divided into three stages (phases). In the first stage, the rights of EU citizens living in the UK and British citizens living in the EU, London's financial obligations to the EU, and the border between the UK and the EU on the island of Ireland were discussed. It should be noted that the negotiation process, which has been going on since June 2017, is quite tense and complicated. Finally, after lengthy negotiations, at the meeting on December 8, 2017, the main issues of the first stage were agreed upon in all three priority areas:

1. Certainly, one of the most challenging issues at the meetings was discussing financial commitments of the UK within the EU, and other financial issues arising in connection with Brexit. The reluctance to pay EUR 60 billion (the amount of compensation the EU was trying to get) was caused by dissatisfaction in London and delay in taking the first phase of the decision (the UK provided EUR 20 billion). As a result, in the last round of negotiations, the parties agreed on a method for determining the final amount of compensation for Britain's withdrawal from the EU. In the end, it turned out that the parties agreed not to disclose the final amount of payments for Britain's withdrawal from the EU, but later, the Prime Minister of the UK, Theresa May, announced the payment of 40 to 44 billion EUR.

2. The UK and the EU agreed to liberate Ireland. Under the agreements, the Republic will refrain from attacking Northern Ireland, and the UK, in turn, agrees to the free movement of goods, services, and citizens across a $360 \mathrm{~km}$ border (i.e., after Brexit, the border between the two parts of Ireland will be opened), and will restore Northern Ireland's autonomy in the UK.

3. Approximately 3 million citizens of the EU live in the UK. Their legal status and rights are one of the most challenging issues in the process of Britain's withdrawal from the EU.

Citizens of the EU living in the UK will have a two-year grace period to apply for the after-Brexit status. This was announced by the Department of Exit from the $\mathrm{EU}$ and the Ministry of the Interior, presenting their plans for mass registration 
programs. Theresa May said that the final agreement guarantees the protection of EU citizens' rights, under British law, in the British courts (see Gatzke, Stahnke, and Schulz, 2017). Finally, there were also agreements on additional issues of negotiations, in particular, such as the withdrawal of the UK from the Union of the Atomic Energy Agency (Euratom), cooperation in civil and commercial matters, police cooperation in criminal matters.

The second stage of the negotiations was to begin in late January or early February 2018. The second stage was to discuss future relations between the UK and the EU following the UK's withdrawal from the EU. This included a time-limited transition period and trade relations issues, and participants had to discuss the terms of the two-year transition period following the UK's withdrawal from the EU. As the UK remains in a customs union and common market during the transitional period, ensuring the free movement of capital and labor will have to follow the EU's trade policy. However, Britain's withdrawal from the EU came on January 31, 2020.

The third stage is the interim agreement, which aims to define the principles and rules according to which cooperation will develop after the UK's withdrawal from the EU. Moreover, before that, the conclusion of all new agreements provided for in the second stage should take place. The transitional provisions will apply for a maximum of two years, after which the UK and the EU will enter into a permanent relationship in their new role.

$* * *$

The following conclusions can be drawn from the UK's European integration development and disintegration process From the beginning of integration processes on the European continent, the peculiarity of the UK's geopolitical position was to preserve its imperial status, the domination of European national interests over the interests of European unity. However, even after its accession to the EU, the development of relations between the UK and Western European countries was characterized by difficulties in finding areas for optimum cooperation, contradictions, and the struggle for leadership.

The specificity of geopolitical thought in the UK is represented by differences in political and legal systems, foreign policy structures and foreign economic priorities, attitudes to cultural identity. The main content of the contradictions in the position of the UK was reduced to a number of problems that caused Brexit, namely: the restrained attitude to the deepening process, differences in the formulation of a common foreign policy, contradictions in the functioning of the EU budget system, fundamental objections to the functioning of the euro area, the EU's immigration policy. 
The referendum on the UK's withdrawal from the EU was a significant challenge for both sides. The withdrawal from the EU can have complex economic and political consequences. Therefore, it was necessary to identify the main problem areas and potential risks. Britain's withdrawal from the EU changes the current reality of international relations in the $21^{\text {st }}$ century. It causes significant changes in the foreign policy of both the UK and European countries.

Certainly, Brexit had a significant impact on the EU's situation and its future. With Britain's departure, one of the EU's political and economic leaders, the EU can expect, above all, radical changes in its organization and politics. The work of the European Commission and the British Government on further cooperation between the EU and the UK can be used to develop models for cooperation between the Eastern Partnership countries and the EU in the future.

\section{References}

Council of the European Union (2020). Covid-19: Council approves EUR 3 billion of aid to partner countries. Retrieved from: https://www.consilium.europa.eu/pl/press/pressreleases/2020/05/05/covid-19-council-greenlights-3-billion-assistance-package-to-supportneighbouring-countries/eu (accessed: 5.05.2020).

Derega, V. (2008). Characteristic features and peculiarities of the enlargement of the European Union. Mariupol: Global and European integration, Mariupol State University: 120-139.

Gatzke, M., Stahnke, J., Schulz, S. (2017). Viel Spaß, Theresa May. Zeit. Retrieved from: http:// www.zeit.de/wirtschaft/2017-03/brexit-grossbritannien-eu (accessed 29.03.2017).

Gschwendtner, C. (2017). Was der Brexit Deutschland kosten könnte. Süddeutsche Zeitung. Retrieved from: https://www.sueddeutsche.de/politik/geld-aus-bruessel-brexit-bedrohtstrukturhilfe-fuer-ostdeutschland-1.3700057 (accessed: 10.11.2017).

Hrubinko, A. (2015). Interaction of the "Big Three" countries in the EU foreign and security policy system. Foreign Affairs, 4: 4-9.

Independent Analytical Centre of Geopolitical Research Borisfen Intel (2015). Fear of migration in Europe. Retrieved from: http://bintel.com.ua/uk/article/01-Migration+fears/ (accessed: 1.12.2015).

Latorre, M., Olekseyuk, Z., Yonezawa, H., Robinson, S. (2019). Brexit: Everyone Loses, but Britain Loses the Most. Peterson Institute for International Economics. Retrieved from: www.piie.com/publications/working-papers/brexit-everyone-loses-britain-loses-most (accessed: 5.03.2019).

Makarenko, M., Khomutenko, L., Diakonova, I. (2014). European integration. Sumy, Kyiv: UABS NBU.

Markova, A., Krivtsova, N., Kvasov, A. (1995). History of world economy, Economic reforms in 1920-1990, Legislation and law. Moskva: Zakon i pravo, UNITY. 
Pogkas, D., Diamond, J. (2020). The EU Risks Tariffs on $€ 47$ Billion Without a Brexit Trade Deal. Bloomberg. Retrieved from: www.bloomberg.com/graphics/2020-no-deal-brexittrade-tariffs-european-union/ (accessed: 28.01.2020).

Vardanean, E. (2017). Results in 2017. "Brexit” becomes inevitable. Part 1, Radio Europe Liberă. Retrieved from: https://www.europalibera.org/a/blog-ernestvardanean/28933524.html (accessed: 22.12.2017). 